\title{
Influence of Fly Ash on the Performance of Recycled Aggregate Concrete
}

\author{
N. Sowmith ${ }^{1}$, P.S.S. Anjaneya Babu ${ }^{2}$ \\ ${ }^{1}$ PG Student, Department Of Civil Engineering, Gudlavalleru Engineering College, India \\ ${ }^{2}$ Assistant Professor, Department Of Civil Engineering, Gudlavalleru Engineering College, India
}

\begin{abstract}
The infrastructure of a country or state depends on the development of innovative ventures constructed in that state/ country. Due to increase in construction the natural aggregates are depleting day by day. So the recycling technique is adopted in construction field. Recycled coarse aggregate (RCA) is one of the approaches for this need. The strength of concrete decrease with increase in the percentage of recycled coarse aggregate but there are methods to increase the strength of RCA such as surface treatments, two stage mixing and pozzolanic material. In this project the method of using pozzolanic material and two stage mixing method is studied, here fly ash is used as pozzolanic material. The paper investigates about the effect of replacement of fly ash on fresh and hardened properties of recycled aggregate concrete. Most of the research work done on replacement of coarse aggregate with recycled aggregates about $25 \%$, $50 \%, 75 \%$ \& $100 \%$ and class $F$. fly ash is used to replace ordinary Portland cement by $10 \%$ \& $20 \%$ to improve the workability and strength of recycled aggregate concrete. The compressive strength and split tensile strength of recycled aggregate concrete is compared with the conventional concrete.
\end{abstract}

Keywords: Compressive strength, fly ash, ordinary Portland cement, Recycled coarse aggregate, Split tensile strength.

\section{Introduction}

Reduce, Re-use, Recycle are the stepping stones for sustainability which is the most basic concern of the present day and the most significant research to be under taken. Concrete is considered as the basic material for every type of construction and is mostly used. This leads to the emission of carbon dioxide and green house gases into the atmosphere which is adding up with the present day polluted sphere. The use of less cement and natural aggregates used in concrete production lowers the impact of concrete industry on the environment. Aggregates, in terms of volume are the major components of concrete and may have significant effect on both engineering properties and the final cost of concrete mixture. Moreover natural resources are depleted remarkably due to extensive use generated by high demand of new buildings and constructions. Every year, it is estimated that the construction industry in India generates about 10-12 million tonnes of waste annually. In the USA, the construction waste produced is 123 million tons per year. In EU, 850 million tons of construction and demolition waste are generated per year. Therefore, as concrete is still the material the most used in civil and industrial infrastructure and is also the major absorbing of natural mineral resources, recycling rubble concrete gains importance. It preserves natural resources and eliminates the need for disposal by using the demolished concrete as an alternative aggregates for new concrete production.

On the other hand, aggregate in fact, is known to play a substantial role in determining workability, strength, dimensional stability, and durability of the concrete. Due to their bonded mortar, recycled concrete aggregates have a lower specific gravity and a higher water absorption capacity compared to natural aggregates. The compressive strength varies with the compressive strength of the old concrete and the water-cementing materials ratio $(\mathrm{w} / \mathrm{c})$ of the new concrete. While recycling old concrete into aggregate, a relatively simple process which involves breaking, removing, and crushing existing concrete into a material with a specified size and quality. The properties of concrete made with RCA are strongly dependent on the quality of the recycled materials used as well as the primary concrete crushed. Indeed, extracting virgin aggregates is causing huge damage to the environment and considerable energy is required for both extraction as well as crushing processes. Thus, a growing interest in substituting natural aggregates with alternative recycled aggregates derived from different constructions and demolitions wastes.

To increases the strength of recycled aggregate concrete there are methods such as surface treatments, mixing methods and use of pozzolanic materials. In surface treatment, collected RCA is cleaned with different acids to increase the strength of RCA. There are three methods of mixing; they are normal mixing method (NM), double mixing method (DM) and triple mixing method $(\mathrm{TM})^{[9]}$ Pozzolanic materials improves the strength of RCA by filling air voids which were occurred in RCA and also by using pozzolanic material it increases the bond strength between motor and cement paste. In the present study double stage mixing method and pozzolanic material is used to increase the strength of RCA. Here fly ash (FA) is undertaken as supplementary cementing materials (SCMs) as replacement for cement. Fly ash is classified into two types class $\mathrm{C}$ and class F. Here class F fly ash is used. Fly ash is a waste product from the thermal power plants and available free of cost. With this the impact on the environment due cement can be reduced. Over years several researches with fly ash as a replacement of cement in concrete production had come up with qualitative results like improvement in the workability and long term strength, reduction in permeability, risk minimization due to alkali silica reaction, lowering in heat of hydration in mass concrete, and enhancement in the durability performance

Volume 5 Issue 6, June 2016 www.ijsr.net 


\section{International Journal of Science and Research (IJSR) \\ ISSN (Online): 2319-7064}

Index Copernicus Value (2013): 6.14 | Impact Factor (2015): 6.391

(resistance to chloride and sulphate attack). Extensive research work has already been performed on the use of fly ash and other supplementary cementitious materials to enhance sustainability and durability of concrete material. In the present investigation $10 \% \& 20 \%$ fly ash is used as replacement to cement and to improve the properties of recycled aggregate concrete. The current investigation attempts to strengthen the RCA with using pozzolanic material and by using two stage mixing method with various proportions of $25 \%, 50 \%, 75 \%$, and $100 \%$ RCA in concrete. Limbachiya et.al and Ouchagour ${ }^{[7],[8]}$ has proven that RCA could successfully be used as a substitute for natural aggregate to produce normal and high strength concrete, meeting required design strength and desire probability performance. They made a general conclusion that up to $30 \%$ RCA can be used as a replacement for natural aggregate without any negative effects on fresh and hardened concrete properties of Portland cement.

\section{Experimental work}

The main objective of this paper is to compare the hardened properties of concrete with different amount of recycled aggregates such as $25 \%, 50 \%, 75 \%$ and $100 \%$. The scope of this investigation is limited to target strength of concrete.

The experimental work for this study includes the materials used, the concrete mixes proportion, tests that has been used for determining the fresh concrete performance and tests that has been conducted for assessing the hardened concrete performance. Mix design was designed as per IS-102622009 as control mix with natural coarse aggregate. The mix proportion was found and finally with the W/C ratio of 0.42 , the control mix was with the $100 \%$ natural coarse aggregates and other mixes were also prepared with $(75 \%+25 \%)$, $(50 \%+50 \%),(75 \%+25 \%)$ and $(100 \%+0 \%)$ combination of natural coarse aggregates and recycled coarse aggregates respectively.

\subsection{Materials Used}

\subsubsection{Cement}

Ordinary Portland cement of 53 grade conforming to IS:

12269-1987 was used for this entire study.

Table 1: Tests on Cement

\begin{tabular}{|c|c|c|c|}
\hline S. No & Particulars of tests & Test results & $\begin{array}{c}\begin{array}{c}\text { Requirements as per IS } \\
\text { codes }\end{array} \\
\end{array}$ \\
\hline 1 & standard consistency & $31 \%$ & IS 4031- 1988 (part-4) \\
\hline 2 & Specific gravity & 3.1 & \\
\hline \multirow{3}{*}{3} & Setting time & & \\
\hline & a) Initial & 98 minutes & $\begin{array}{c}\text { As per } 12269-201330 \\
\text { min. Minimum }\end{array}$ \\
\hline & b) Final & 300 minutes & $\begin{array}{c}\text { As per } 12269-2013600 \\
\text { min. Maximum }\end{array}$ \\
\hline
\end{tabular}

\subsubsection{Fine Aggregate}

Locally available river sand passing through IS sieve $4.75 \mathrm{~mm}$ was used as fine aggregate and the following tests were carried out on a sand as per IS 2386- 1986 (part 3).
Table 2: Tests on Fine Aggregate.

\begin{tabular}{|c|c|c|}
\hline S. No & Particulars of test & Test results \\
\hline 1 & Specific gravity & 2.53 \\
\hline 2 & Water absorption $(\%)$ & 1.35 \\
\hline 3 & Bulk density $\left(\mathrm{kg} / \mathrm{m}^{3}\right)$ & 1680 \\
\hline 4 & Sieve analysis & Zone II \\
\hline
\end{tabular}

\subsubsection{Coarse Aggregate}

For this study, two types of coarse aggregates were used for the preparation of concrete i.e. Natural coarse aggregate (NCA) and Recycled coarse aggregate (RCA). Both NCA and RCA aggregates were screened into two different size fractions (i.e. $70 \%$ of $20 \mathrm{~mm}$ to $16 \mathrm{~mm}$ sized and $30 \%$ of $12 \mathrm{~mm}$ to $10 \mathrm{~mm}$ sized) and combined to form NCA \& RCA.

\subsubsection{Natural coarse aggregate}

For this study, locally available crushed stone aggregate of size $20 \mathrm{~mm}$ were used and the following tests were carried out on NCA.

Table 3: Tests on Coarse Aggregate

\begin{tabular}{|c|c|c|}
\hline S. No & Particulars of test & Test results \\
\hline 1 & Specific gravity & 2.76 \\
\hline 2 & Fineness modulus & 3.32 \\
\hline 3 & Crushing value $(\%)$ & 19.69 \\
\hline 4 & Impact value $(\%)$ & 23.20 \\
\hline
\end{tabular}

\subsubsection{Recycled Aggregate}

Recycled aggregate were prepared by crushing the M40 grade manufactured cubes. The cubes were cured for 28days and broken into smaller pieces by hammer then sieved to collect maximum size of $20 \mathrm{~mm}$ and minimum size of $10 \mathrm{~mm}$. The following tests were carried out on RCA.

Table 4: Tests on Recycled Coarse Aggregate

\begin{tabular}{|c|c|c|}
\hline S. No & Particulars of test & Test results \\
\hline 1 & Specific gravity & 2.61 \\
\hline 2 & Fineness modulus & 3.57 \\
\hline 3 & Crushing value (\%) & 17.23 \\
\hline 4 & Impact value (\%) & 20.61 \\
\hline
\end{tabular}

\subsubsection{Water}

In this study portable water conforming to IS: 456-2000 was used for casting and curing.

\subsubsection{Fly Ash}

In this study class F fly ash was used as pozzalonic material to replace cement.

\section{Mix Design}

Concrete mix proportions were designed as per IS 10262: 2009 code with the target slump of $25-50 \mathrm{~mm}$. A super plasticizer of SP430 was used for high degree of workability. The content of super plasticizer was $0.8 \%$ of cement used. The resulting concrete is proportioned for M40 grade as per nominal mix design. The natural coarse aggregate is replaced by recycled coarse aggregate in percentages i.e., $0 \%, 25 \%, 50 \%, 100 \%$ and these specimens were tested for compression and split tensile strengths. The variations of compressive strength and split tensile strength 


\section{International Journal of Science and Research (IJSR) \\ ISSN (Online): 2319-7064}

Index Copernicus Value (2013): 6.14 | Impact Factor (2015): 6.391

with fly ash and without fly ash are discussed in the result section.

\subsection{Mix Proportions}

Here three mixes of concrete were prepared i.e., Mix - 01, Mix - 02 and Mix - 03. Mix - 01 was prepared by using fly ash as cement replacement by $10 \%$ with w/c ratio 0.42 , Mix -02 was prepared by using fly ash as cement replacement by $20 \%$ with w/c ratio 0.42 and Mix - 03 was prepared without using fly ash with w/c ratio 0.45 . The crushed aggregates are used for the replacement of natural aggregates in different proportions such as $0 \%, 25 \%, 50 \%, 75 \%$, and $100 \%$.

Table 5: Mix 01, with $10 \%$ fly ash (w/c 0.42)

\begin{tabular}{|c|c|c|c|c|c|c|c|c|}
\hline \multirow{2}{*}{$\begin{array}{c}\text { S. } \\
\text { No }\end{array}$} & \multicolumn{2}{|c|}{$\%$ of replacement } & \multirow{2}{*}{$\begin{array}{l}\text { Cement } \\
\left(\mathrm{kg} / \mathrm{m}^{3}\right)\end{array}$} & \multirow{2}{*}{$\begin{array}{c}\text { Fly } \\
\text { Ash }\left(\mathrm{kg} / \mathrm{m}^{3}\right)\end{array}$} & \multirow[t]{2}{*}{ Sand $\left(\mathrm{kg} / \mathrm{m}^{3}\right)$} & \multirow[t]{2}{*}{ Water $\left(\mathrm{kg} / \mathrm{m}^{3}\right)$} & \multirow[t]{2}{*}{ NCA $\left(\mathrm{kg} / \mathrm{m}^{3}\right)$} & \multirow[t]{2}{*}{$\operatorname{RCA}\left(\mathrm{kg} / \mathrm{m}^{3}\right)$} \\
\hline & NCA (\%) & RCA (\%) & & & & & & \\
\hline 01 & 75 & 25 & 373.32 & 41.48 & 842.06 & 177.77 & 827.54 & 275.84 \\
\hline 02 & 50 & 50 & 373.32 & 41.48 & 842.06 & 177.77 & 551.69 & 551.69 \\
\hline 03 & 25 & 75 & 373.32 & 41.48 & 842.06 & 177.77 & 275.84 & 827.54 \\
\hline 04 & 0 & 100 & 373.32 & 41.48 & 842.06 & 177.77 & 0 & 1103.39 \\
\hline
\end{tabular}

Table 6: Mix 02, with 20\% fly ash (w/c 0.42)

\begin{tabular}{|c|c|c|c|c|c|c|c|c|}
\hline \multirow{2}{*}{$\begin{array}{l}\text { S. } \\
\text { No }\end{array}$} & \multicolumn{2}{|c|}{$\%$ of replacement } & \multirow{2}{*}{$\begin{array}{l}\text { Cement } \\
\left(\mathrm{kg} / \mathrm{m}^{3}\right)\end{array}$} & \multirow{2}{*}{$\begin{array}{l}\text { Fly Ash } \\
\left(\mathrm{kg} / \mathrm{m}^{3}\right)\end{array}$} & \multirow[t]{2}{*}{ Sand $\left(\mathrm{kg} / \mathrm{m}^{3}\right)$} & \multirow[t]{2}{*}{ Water $\left(\mathrm{kg} / \mathrm{m}^{3}\right)$} & \multirow[t]{2}{*}{$\operatorname{NCA}\left(\mathrm{kg} / \mathrm{m}^{3}\right)$} & \multirow[t]{2}{*}{$\mathrm{RCA}\left(\mathrm{kg} / \mathrm{m}^{3}\right)$} \\
\hline & $\operatorname{NCA}(\%)$ & RCA (\%) & & & & & & \\
\hline 01 & 75 & 25 & 331.84 & 82.96 & 842.06 & 177.77 & 827.54 & 275.84 \\
\hline 02 & 50 & 50 & 331.84 & 82.96 & 842.06 & 177.77 & 551.69 & 551.69 \\
\hline 03 & 25 & 75 & 331.84 & 82.96 & 842.06 & 177.77 & 275.84 & 827.54 \\
\hline 04 & 0 & 100 & 331.84 & 82.96 & 842.06 & 177.77 & 0 & 1103.39 \\
\hline
\end{tabular}

Table 7: Mix 03, without fly ash (w/c 0.45)

\begin{tabular}{|c|c|c|c|c|c|c|c|}
\hline \multirow[t]{2}{*}{ S. No } & \multicolumn{2}{|c|}{$\%$ of replacement } & \multirow{2}{*}{$\begin{array}{l}\text { Cement } \\
\left(\mathrm{kg} / \mathrm{m}^{3}\right)\end{array}$} & \multirow[t]{2}{*}{ Sand $\left(\mathrm{kg} / \mathrm{m}^{3}\right)$} & \multirow[t]{2}{*}{ Water $\left(\mathrm{kg} / \mathrm{m}^{3}\right)$} & \multirow[t]{2}{*}{$\mathrm{NCA}\left(\mathrm{kg} / \mathrm{m}^{3}\right)$} & \multirow[t]{2}{*}{$\operatorname{RCA}\left(\mathrm{kg} / \mathrm{m}^{3}\right)$} \\
\hline & NCA (\%) & RCA (\%) & & & & & \\
\hline 01 & 100 & 0 & 414.81 & 842.06 & 186.66 & 1103.39 & 0 \\
\hline 02 & 75 & 25 & 414.81 & 842.06 & 186.66 & 827.54 & 275.84 \\
\hline 03 & 50 & 50 & 414.81 & 842.06 & 186.66 & 551.69 & 551.69 \\
\hline 04 & 25 & 75 & 414.81 & 842.06 & 186.66 & 275.84 & 827.54 \\
\hline 05 & 0 & 100 & 414.81 & 842.06 & 186.66 & 0 & 1103.39 \\
\hline
\end{tabular}

\subsection{Mixing Procedure}

Mixing of ingredients is done in pan mixer of capacity 40 litres. The cementations materials are thoroughly blended and then the aggregate is added and mixed followed by gradual addition of water and mixing. Mixing is done until a mixture of uniform colour and consistency are achieved which is then ready for casting. Mixing of concrete is done by Double mixing method ${ }^{[15]}$.

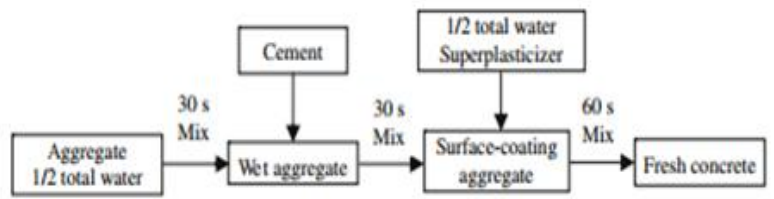

Figure 1: Double mixing method coated with cement and admixture

\section{Tests on fresh and hardened concrete}

\subsection{Slump Test}

Slump test is the most commonly used method \& measuring consistency of concrete which - be employed either in laboratory or at site work. For the present work, slump tests were conducted as per IS: $1199-1959$ for all mixes. It is not suitable method for vary wet or very dry concrete. This method is suitable for medium slump. The apparatus for conducting the slump test essentially consists a metallic Mould in the form of frustum of a cone having the dimensions of top diameter $10 \mathrm{~cm}$, bottom diameter $20 \mathrm{~cm}$ and height $30 \mathrm{~cm}$. For tamping the concrete; a steel tamping rod is $16 \mathrm{~mm}$ diameter, $0.6 \mathrm{~m}$ along with bullet is used. The mould is placed on a smooth, horizontal, rigid and nonabsorbent surface. The mould is then filled in four layers, each approximately $1 / 4^{\text {th }}$ of the height of the mould. Each layer is tamped 25 times by the tamping rod taking care to distribute the strokes evenly over the cross section.

\subsection{Compressive Strength}

The cubes of size $150 \times 150 \times 150 \mathrm{~mm}$ were casted. After 24 hours, the specimens are removed from the moulds and subjected to curing for 7 days and 28 days in portable water. After curing, the specimens are tested for compressive strength using compression testing machine of $2000 \mathrm{KN}$ capacity (IS: $516-1959$ ). The maximum load at failure is taken. The average compressive strength of concrete specimens is calculated by using the following equation.

Compressive strength of concrete $=\frac{\text { Ultimate compressive load }(N)}{\text { Area of cross section }(\mathrm{mm} \text { square })}$

\subsection{Split tensile Strength}

The cylinders are of size $150 \mathrm{~mm}$ diameter and $300 \mathrm{~mm}$ length is casted. After 24 hours, the specimens are removed from the moulds and subjected to curing for 7 days and 28 days in portable water. After curing, the specimens are tested for split tensile strength using compression testing machine of $2000 \mathrm{KN}$ capacity (IS: 516 - 1959). The maximum load at failure is taken. The ultimate load is taken

\section{Volume 5 Issue 6, June 2016 www.ijsr.net}




\section{International Journal of Science and Research (IJSR) \\ ISSN (Online): 2319-7064}

Index Copernicus Value (2013): 6.14 | Impact Factor (2015): 6.391

and the average Split tensile Strength is calculated using the equation.

split tensile strength $=\frac{2 \times \text { Ultimate compressive load }(N)}{\pi \times \text { length } \times \text { Diameter }(\text { mm square })}$

\section{Results and discussions}

\subsection{Slump}

Workability of the three mixes Mix 1, Mix 2 and Mix 3 is gradually decreased with increase in percentage of recycled aggregates. The set with $20 \%$ fly ash has more workability than without fly ash. Workability with different \% of RCA (in slump value) is shown in table 8.

Table 8: Workability for Mix with different $\%$ of FA and RCA

\begin{tabular}{|c|c|c|c|c|c|c|}
\hline $\begin{array}{c}\% \\
\text { replacemen }\end{array}$ & \multicolumn{2}{|l|}{ Without Fly Ash } & \multicolumn{2}{c|}{$\begin{array}{c}\text { With 10\% Fly } \\
\text { Ash }\end{array}$} & $\begin{array}{c}\text { With 20\% fly } \\
\text { ash }\end{array}$ \\
\cline { 2 - 8 } t of RCA & w/c ratio & slump & w/c ratio & slump & w/c ratio & slump \\
\hline 0 & 0.45 & 45 & 0.45 & 45 & 0.45 & 45 \\
\hline 25 & 0.45 & 42 & 0.42 & 41 & 0.42 & 40 \\
\hline 50 & 0.45 & 38 & 0.42 & 37 & 0.42 & 37 \\
\hline 75 & 0.45 & 33 & 0.42 & 34 & 0.42 & 35 \\
\hline 100 & 0.45 & 30 & 0.42 & 32 & 0.42 & 33 \\
\hline
\end{tabular}

\subsection{Compressive Strength}

The experimental results obtained after the curing of 7 days and 28 days are shown in the table 9 and figure 2, 3. The compressive strength of the two sets is decreased with the increase in percentage of recycled aggregates. Generally, $30 \mathrm{MPa}$ strength value is widely used in construction purposes. At 28 days $100 \%$ replacement of RCA with addition of fly ash achieves strength of $38.18 \mathrm{Mpa}$. In long period of time this strength can the equal or exceed to the strength of natural aggregate concrete.

Table 9: Compressive strength for 7 and 28 days with and without fly ash

\begin{tabular}{|c|c|c|c|c|c|c|}
\hline $\begin{array}{c}\% \\
\text { replacement } \\
\text { of RCA }\end{array}$ & \multicolumn{2}{|c|}{\begin{tabular}{c} 
without fly ash \\
\cline { 2 - 7 }
\end{tabular}} & $\begin{array}{c}\text { with 10\% fly ash } \\
\text { Strength (Mpa) }\end{array}$ & \multicolumn{2}{c|}{$\begin{array}{c}\text { With 20\% fly ash } \\
\text { strength (Mpa) }\end{array}$} & \multicolumn{2}{c|}{$\begin{array}{c}\text { compressive } \\
\text { strength, (Mpa) }\end{array}$} \\
\cline { 2 - 7 } & 7 days & 28 days & 7 days & 28 days & 7 days & 28 days \\
\hline 0 & 42.74 & 53.40 & 42.74 & 53.40 & 42.74 & 53.40 \\
\hline 25 & 38.47 & 50.75 & 39.48 & 51.21 & 36.31 & 48.17 \\
\hline 50 & 33.32 & 46.45 & 34.71 & 48.17 & 29.91 & 43.41 \\
\hline 75 & 29.85 & 44.31 & 31.65 & 45.42 & 28.33 & 41.41 \\
\hline 100 & 27.75 & 42.16 & 29.31 & 43.82 & 25.58 & 38.18 \\
\hline
\end{tabular}

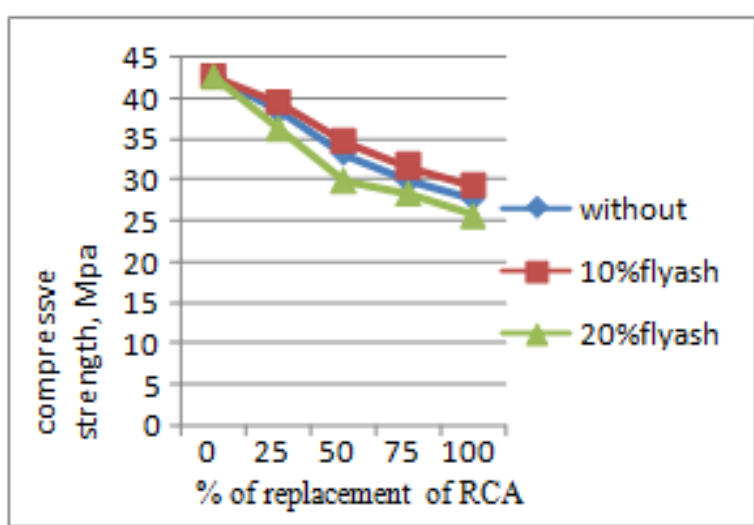

Figure 2: Compressive strength of concrete for 7 days.

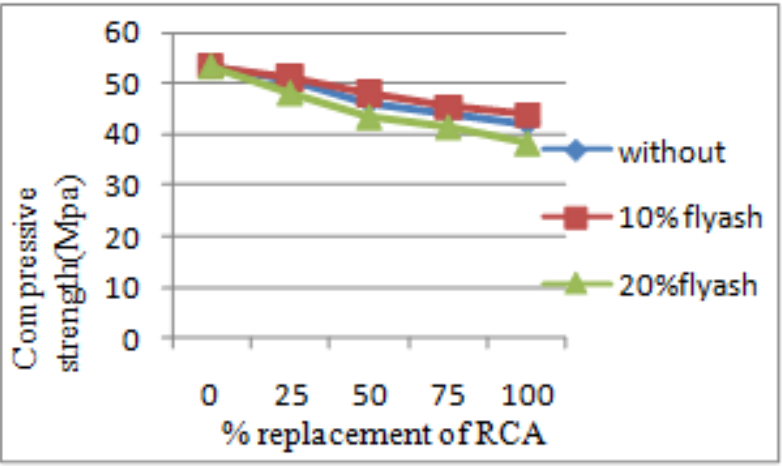

Figure 3: Compressive strength of concrete for 28 days.

\subsection{Split Tensile Strength}

The split tensile strength results obtained after the curing of 7 days and 28 days are shown in the table 10 and figure 5, 6 . The split tensile strength of the two sets is also decreased with the increase in percentage of recycled aggregates. The split tensile strength decreases with increase in the percentage of fly ash.

Table 10: Split Tensile strength for 7 and 28 days with and without fly ash

\begin{tabular}{|c|c|c|c|c|c|c|}
\hline $\begin{array}{c}\% \\
\text { replacement } \\
\text { of RCA }\end{array}$ & \multicolumn{2}{|c|}{ without fly ash } & \multicolumn{2}{|l|}{ With 10\% fly ash } & \multicolumn{2}{|c|}{$\begin{array}{c}\text { With 20\% fly } \\
\text { ash }\end{array}$} \\
\cline { 2 - 7 } & \multicolumn{2}{|c|}{$\begin{array}{c}\text { Split Tensile } \\
\text { strength, Mpa }\end{array}$} & \multicolumn{2}{|c|}{$\begin{array}{c}\text { Split Tensile } \\
\text { strength, Mpa }\end{array}$} & \multicolumn{2}{|c|}{$\begin{array}{c}\text { Split Tensile } \\
\text { strength, Mpa }\end{array}$} \\
\cline { 2 - 7 } & 7 days & 28 days & 7 days & 28 days & 7 days & 28 days \\
\hline 0 & 3.50 & 3.83 & 3.50 & 3.83 & 3.50 & 3.83 \\
\hline 25 & 3.29 & 3.71 & 3.17 & 3.55 & 2.82 & 2.94 \\
\hline 50 & 3.15 & 3.59 & 2.82 & 3.36 & 2.64 & 2.84 \\
\hline 75 & 3.03 & 3.55 & 2.62 & 3.19 & 2.54 & 2.73 \\
\hline 100 & 2.97 & 3.51 & 2.54 & 2.94 & 2.46 & 2.69 \\
\hline
\end{tabular}

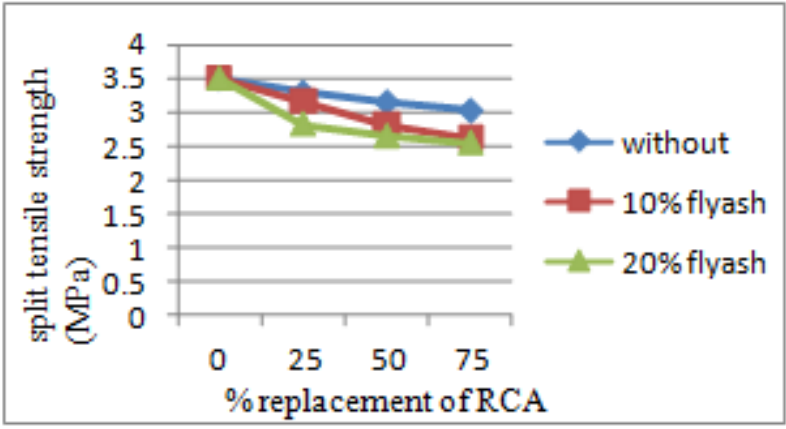

Figure 4: Split tensile strength of concrete for 7 days.

\section{Volume 5 Issue 6, June 2016 www.ijsr.net}




\section{International Journal of Science and Research (IJSR) \\ ISSN (Online): 2319-7064}

Index Copernicus Value (2013): 6.14 | Impact Factor (2015): 6.391

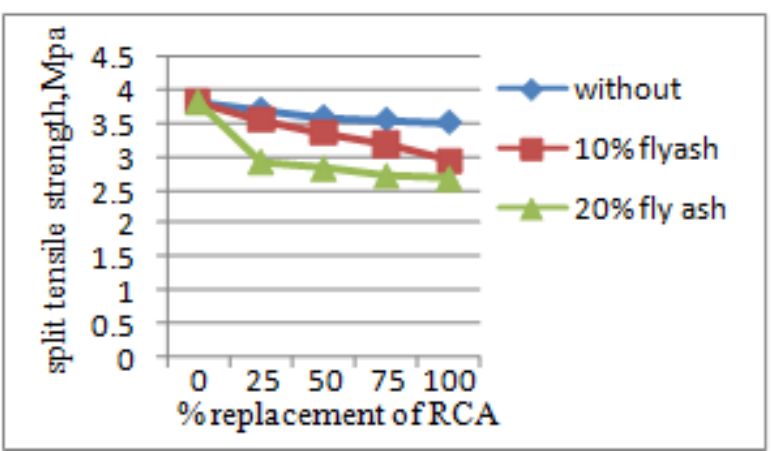

Figure 5: Split Tensile strength for 28 days.

\section{Conclusions}

From the study following conclusions are made

1) The strength of concrete decrease with increase in the percentage of recycle aggregate, this may be because of the loose mortar around the recycle aggregate which do not allow the proper bonding between the cement paste and aggregate.

2) Workability of RAC concrete can be improved by replacing cement with fly ash about $10 \%$ and $20 \%$ by weight of cement.

3) The strength (30Mpa) is generally used for a wide range of structural uses. From the present study it is concluded that by decreasing the water to cement ratio to 0.42 , the above strength can be achieved through recycled aggregates and fly ash.

4) Generally, fly ash based concrete has the ability to develop strength over prolonged periods of time. So at a long period of run the compressive strength of RAC with fly ash achieves similar strength of natural aggregate concrete by adding fly ash.

5) In conclusion, if properly designed RAC, especially that containing fly ash, can be an effective alternative to natural concrete for structural purposes.

\section{References}

[1] Y. V. Akbari, N. K. Arora, M. D. Vakil, "Effect on recycled aggregate on concrete properties", International Journal of Earth Sciences and Engineering ISSN 0974-5904, Volume 04, No 06 SPL, October 2011, pp. 924-928.

[2] A.K. Padmini, K. Ramamurthy , M.S. Mathews, "Influence of parent concrete on the properties of recycled aggregate concrete", Construction and Building Materials 23 (2009) 829-836.

[3] Sudhir p.patil, ganesh single, prashant d.sathe, "Recycled coarse aggregates", International Journal of Advanced Technology in Civil Engineering, ISSN: 2231 -5721, Volume-2, Issue-1, 2013.

[4] Dabhade A.N., Choudhari S.R., Gajbhiye A.R., "Experimental study of effects of fly-ash on recycled concrete", International journal of applied engineering and technology ISSN: 2277-212X(online).

[5] Shi-Cong Kou,Chi-Sun Poon, "Long-term mechanical and durability properties of recycled aggregate concrete prepared with the incorporation of fly ash", Cement \& Concrete Composites 37 (2013) 12-19.

[6] Carmine Lima, Antonio Caggiano, Ciro Faella, Enzo Martinelli, Marco Pepe, Roberto Realfonzo, "Physical properties and mechanical behaviour of concrete made with recycled aggregates and fly ash", Construction and Building Materials 47 (2013) 547-559.

[7] Limbachiya M ,Meddah MS, Ouchagour Y. "Performance of Portland/silica fume cement concrete produced with recycled concrete aggregate", ACI Mater J, submitted for publication [M-2010-320R2].

[8] Ouchagour Y. "Sustainability of recycled concrete aggregate for use in binary cement concrete". $\mathrm{PhD}$ thesis, Kingston University London, UK; 2007. p. 340

[9] Deyu Kong, Ting Lei, Jianjun Zheng, Chengchang Ma, Jun Jiang, Jing Jiang, "Effect and mechanism of surface-coating pozzalanics materials around aggregate on properties and ITZ microstructure of recycled aggregate concrete", Construction and Building Materials 24 (2010) 701-708 